\title{
EMPIRICAL EVIDENCE ABOUT DIFFERENCES IN HUMAN RESOURCE CONDITIONS BETWEEN INNOVATION- AND IMITATION-BASED ECONOMIES
}

The income and technological inequalities between countries can be derived from differences in country-specific conditions of technological progress. Innovation requires appropriate human resources and institutional environment, as well as firms to innovate. Differences in human, financial and institutional conditions create technology disparities which lead to innovation- and imitation-based economies with different economic performan$c e$. Technological changes in the economy are made possible by the creation and application of new knowledge. Therefore, technological progress can be interpreted as a specific form of knowledge accumulation, in which the human resources of the countries play a key role. This research aims to illustrate the inequalities of innovation's human resource conditions between innovation- and imitation-based economies based on non-parametric and multivariate statistical methods. Variables from the human capital and research pillar of the Global Innovation Index will be compared using different analytical techniques to highlight where the bigger gaps in human resource conditions between country groups are. The main result of this research is that school life expectancy is the factor in which the countries are the most differentiated, so increasing participation in education is important for imitator countries to catch-up with innovation leaders.

Keywords: technological progress; innovation; imitation; human resources

* J. Csugány, Ph.D., Senior lecturer, Eszterházy Károly University, Faculty of Economics and Social Sciences, Institute of Economics, Department of Economics, Eger, Hungary (E-mail: csugany. julianna@uni-eszterhazy.hu).

The paper was received on March 31st, 2018. It was accepted for publication on July 21st, 2018. 


\section{Introduction}

The worldwide dynamic development of technology started more than 200 years ago, with the Industrial Revolution. According to Mokyr (2004) the complementarity of radical innovations, i.e. macroinventions, and incremental innovations, i.e. microinventions, accounted for the enormous economic impact of Industrial Revolution, which launched not only technological progress, but also an increase in the income of the world's countries. Based on the summarized empirical evidence of Williamson (2017) and Jones (2016), the standard of living in the countries of the world did not change prior to the Industrial Revolution and there were no large income differences among the countries either. Thus, economic growth and technological progress occur in close interaction. At the end of the $20^{\text {th }}$ century, the appearance of new information and communication technologies gave a new impetus to development. Due to this, the analysis of technological changes is in the center of economics' interest again.

The ideas embodied in technology as a new form of knowledge, with extensive practical application allows more efficient operation of the economy, leading to growth. Most countries are unable to create new technologies because they do not have the appropriate physical and human resources or the institutional environment do not favor to innovation. However, technological progress can also be observed in these countries, by adapting the new technologies developed and applied effectively elsewhere. Human capital is also essential for the creation and adaptation of technology, so human resource conditions determine the technological development path of the countries. This research aims to illustrate the differences in human resource conditions between countries who can create new technologies, i.e. innovation-based economies and those ones, who can only adapt them, i.e. imitation-based economies. Using nonparametric and multivariate statistical methods, human areas can be identified where these countries are the most different. This can help us to identify which areas of imitation countries need to develop to converge with leaders. Thus, they can enjoy better the benefits of technological progress.

\section{THE ROLE OF HUMAN RESOURCES IN TECHNOLOGICAL PROGRESS AND ECONOMIC GROWTH}

There is a consensus among economists that technological progress is the driving force of economic growth. It requires physical and human capital, as well as appropriate institutions to generate productivity growth which leads to econom- 
ic growth. Solow (1957) pointed out that there is a part of economic growth that cannot be explained by the accumulation of classical production factors, i.e. capital and labor. Therefore, in the long run, economic growth can only be achieved by technological progress which is realized in the growth of total factor productivity. Mankiw, Romer \& Weil (1992) developed the Solow model further and it was complemented by human capital. The authors concluded that the exogenous savings rate coupled with higher levels of human resources generates higher income, so human capital is the determining factor of economic growth. The microeconomic models of endogenous growth theory implicitly assume the existence of institutions that ensure the realization of innovation and the accumulation of human capital (Czeglédi 2004). Examining Asian economic miracles, Lucas (1993) also highlighted that, in the long run, income levels are strongly correlated with the initial stock of human capital.

Several empirical studies confirm that the higher-income countries are typically technologically more advanced, their innovation activity is more intensive and they create the majority of the innovations, in contrast with the lower-income countries, which are typically technology followers, and can adapt new technologies through the imitation of technological leaders (Barro \& Sala-i-Martin, 1997; Acemoglu, Aghion \& Zilibotti, 2006; Basu \& Weil, 1998; Jerzmanowski, 2006). Based on this, technological progress happens in different ways in different countries of the world, depending on their income levels. Thus, technological progress can be achieved through own research and development activities creating new technologies, that is an innovation-driven way, and by adapting new technologies that are already effective in other countries, that is an imitation-driven way. Human capital is also essential for the creation and adaptation of technology, so the quantitative and qualitative characteristics of the human resources endowments in the countries determine the conditions of the technological progress basically. Creating and adapting a new technology requires different skills and capabilities, so different features of human resources can emerge in technology leaders and followers.

Human capital is the set of skills and capabilities that enable people to create new ideas and to apply new technologies. The individual's abilities are shaped and expanded through learning, so human capital can be developed through formal and informal learning, as well as interaction between individuals (knowledge transfers). Simplified, innovation is the embodiment of knowledge gained through education and professional experience. In an economy, the quantity of human capital also depends on the intertemporal decision of individuals who can spend their resources in expanding their current knowledge that influences the current level of productivity or the development of future knowledge that expands the potential of the economy (Lucas, 1988). In connection with technological progress, Nelson \& Phelps (1966) highlighted the importance of education in a new context, tak- 
ing into account the different technological levels of countries, and passing on the different forms of implementation of technological progress. Their model is based on the assumption that there are two types of technology in one economy. There is a technological level realized by potential technological leaders, which can be considered as the world technological frontier. The other technology level is practically realized with the resources available in a given economy. The authors assume that the potentially available technology level will grow at a constant rate that technological follow-up countries have no influence, and that is given them. However, in practice, the technology level in each country is in direct proportion to the quality of education ceteris paribus. With the increase in the average educational level, a technological level can also reach the potential level in a technologyfollower country. Thus, in the model of Nelson and Phelps, the gap between the potentially available and practically applied technology is inversely proportional to the quality of education, so improving the educational quality results in a gap reduction. The authors also pointed out the role of education in the diffusion of technology, assuming that a better-qualified manager is introducing new production techniques faster and he is a better innovator, meaning that skilled workers are important both in adaptation and innovation. According to this, Jovanovic (1997) also pointed out that the physical and human capital required for the application of the new technology is given for all countries, but higher skilled and betterperforming workforce is needed for better technology.

Emphasizing the role of human capital in technological progress, Caselli \& Coleman (2006) pointed out that the technological differences between countries are due to the qualification asymmetry, because innovation requires more skilled workforce, while the less skilled workforce is suitable for imitation. By distinguishing the efficiency of skilled and unskilled labor, the authors can model the world technology frontier. At the frontier, the high-skilled workforce dominates, while far away from the frontier the qualified workforce is replaced by the less qualified one. In higher-income countries, there are more skilled workers, and therefore, these countries choose technology that requires high-skilled labor, whose labor productivity is higher. In contrast, lower-income countries choose technology that is better suited to the unskilled labor force which is better available to them. Aghion \& Howitt (2005) used investment-based growth as a synonym for imitation-based growth, because they emphasized that the adaption of new technology is costly, but it is cheaper than creation of a new one. According to Growiec (2006) the world technology frontier is the most advanced technology available in the world, while Caselli \& Coleman (2006, p.510) specifies that it is the highest level of technology that can be reached without limits. In Islam (2010) calculations, this technology level is presumably the technology level in the United States. Using the concept of world technology frontier, the role of factor endowments, as well as institutions can be emphasized in technology choice. According to Fagerberg (1994) 
two conditions are required for less developed countries to adapt new technology, i.e. social capability and technological congruence. To model technological differences related to human resource conditions between countries, many authors apply the concept of the world technology frontier, which is also capable to differentiate countries based on their technical, human and economic characteristics.

\section{DIFFERENTIATING BETWEEN INNOVATION- AND IMITATION-BASED ECONOMIES: PREVIOUS RESEARCH RESULTS}

Technological progress can be realized innovation- and imitation-driven way, in brief, innovation is the invention of new technologies, while imitation is the adoption of existing technologies (Acemoglu 2009, p.745). A country can adapt a new technology depends on its own capabilities, these features also determine the conditions for creating technology. According to Krugman (1979), innovation is realized in developed countries, because there are knowledge and skills required by invention, as well as material resources that are complemented by an appropriate institutional background. Barro \& Sala-i-Martin (1997) pointed out that imitation is cheaper for less developed countries. Romer (1993) emphasized that developing countries can gain by using ideas produced elsewhere, but there is a great risk in adapting technologies because institutions are different. It seems that innovation- and imitation-based economies should be differentiating.

In a previous research based on the theoretical concept of world technology frontier, 139 countries were classified into the categories of innovation- and imitation-based economies (Csugány, 2016). A novel index was created to measure the main characteristics of the technological and institutional environment. Based on the relevant literature, my analysis includes 28 indicators from the Global Competitiveness Index published by the World Economic Forum, which properly characterize the institutional environment of technological progress. These variables have been supplemented by the 5 indicators of the Economic Freedom of the World (EFW) which cover areas not measured by the previous database. For technological progress, the essential factors are property rights and human capital, while the business, legal and regulatory environment is also important through the possession of power. The market structure and market possibilities influence the invention and diffusion of the new technology. These six separate areas can cover the main country-specific features of technological progress. Through principal component analysis, the examined 33 indicators can be combined into an aggregate indicator which contains only the most important indicators of the technological-institutional environment. The aim of creating the new indicator was 
to reduce data volume and to keep, as a result, in a single indicator only the most relevant features of technological-institutional environment. Finally, the principal component includes 19 variables, which makes it possible to measure the impact of property rights, education and research infrastructure, financing arrangements, the role of firms, and the business, legal and regulatory environment created by the government and the market structure. Based on the relationship between the novel index of technological-institutional environment created by principal component analyis and GDP per capita, the countries can be classified. The purpose of cluster analyis was to sort countries into homogeneous groups along these two factors. This method can be used to create clusters that are as homogenous as possible, but differ from each other as much as possible (Tánczos 2011, p.69). This differentiation allows us to investigate the differences of the country-specific background in innovation- and imitation-driven countries. As a result of the cluster analysis, 23 out of 139 countries belong to the first - innovator - cluster with higher values, and 116 to the lower - imitation - ones (see in Figure 1).

This novel measurement-based classification leads to similar results as the differentiation based on Summary Innovation Index and Global Innovation index, but the new classification extends to a wider range of countries, so it can be used in this research. It is the basis of innovator and imitator group formation. 


\section{Figure 1.}

\section{DIFFERENTIATION OF INNOVATION- AND IMITATION-BASED ECONOMIES BASED ON TECHNOLOGICAL-INSTITUTIONAL ENVIRONMENT INDEX AND GDP PER CAPITA}

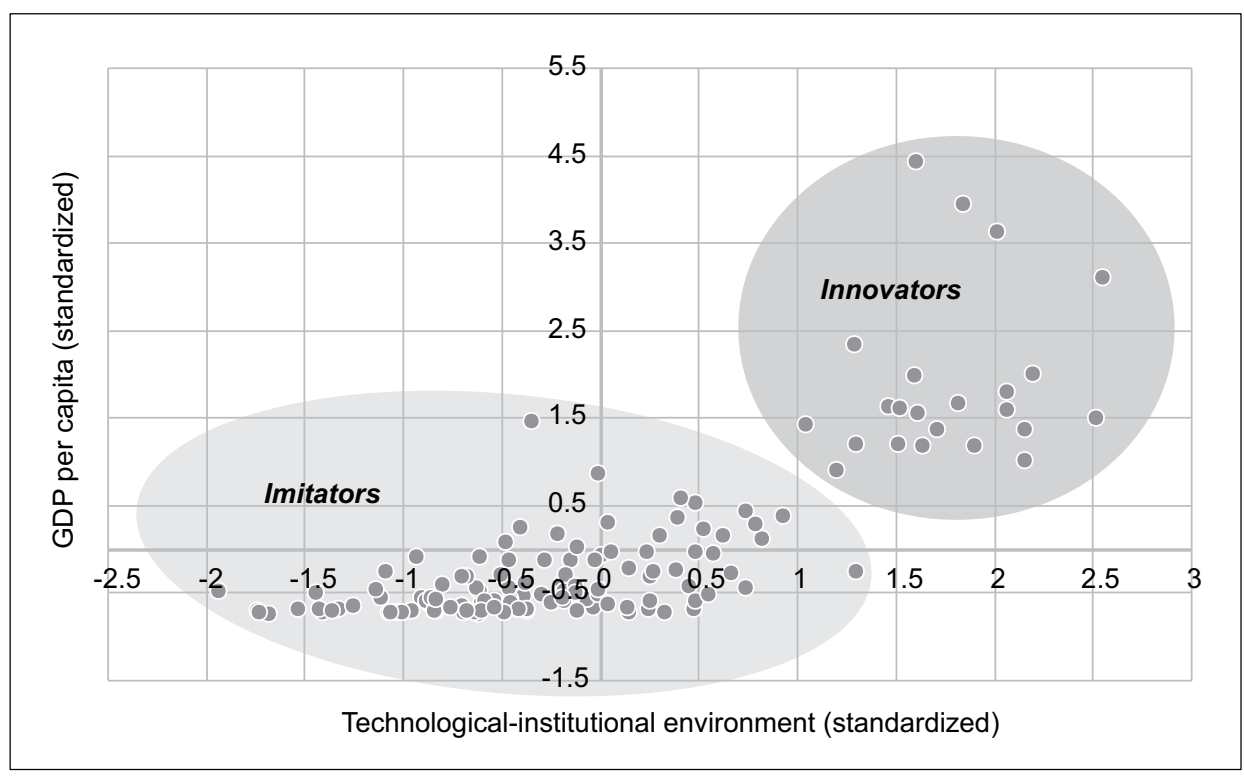

Note: Innovators are Australia, Austria, Belgium, Canada, Denmark, Finland, France, Germany, Iceland, Ireland, Israel, Japan, Luxembourg, Netherlands, New Zealand, Norway, Qatar, Singapore, Sweden, Switzerland, United Arab Emirates, United Kingdom, and United States.

Imitators are Albania, Algeria, Angola, Argentina, Armenia, Azerbaijan, Bahrain, Bangladesh, Barbados, Benin, Bhutan, Bolivia, Bosnia and Herzegovina, Botswana, Brazil, Bulgaria, Burkina Faso, Burundi, Cambodia, Cameroon, Cape Verde, Chad, Chile, China, Colombia, Costa Rica, Côte d'Ivoire, Croatia, Cyprus, Czech Republic, Dominican Republic, Ecuador, Egypt, El Salvador, Estonia, Ethiopia, Gabon, Gambia, Georgia, Ghana, Greece, Guatemala, Guinea, Guyana, Haiti, Honduras, Hungary, India, Indonesia, Iran, Islamic Rep., Italy, Jamaica, Jordan, Kazakhstan, Kenya, Korea, Rep., Kuwait, Kyrgyz Republic, Latvia, Lebanon, Lesotho, Lithuania, Macedonia, FYR, Madagascar, Malawi, Malaysia, Mali, Malta, Mauritania, Mauritius, Mexico, Moldova, Mongolia, Montenegro, Morocco, Mozambique, Namibia, Nepal, Nicaragua, Nigeria, Oman, Pakistan, Panama, Paraguay, Peru, Philippines, Poland, Portugal, Romania, Russian Federation, Rwanda, Saudi Arabia, Senegal, Serbia, Seychelles, Sierra Leone, Slovak Republic, Slovenia, South Africa, Spain, Sri Lanka, Suriname, Swaziland, Tanzania, Thailand, Timor-Leste, Trinidad and Tobago, Tunisia, Turkey, Uganda, Ukraine, Uruguay, Vietnam, Yemen, Zambia, and Zimbabwe.

Source: own construction based on Csugány (2016) 


\section{RESEARCH QUESTIONS, DATA AND METHODOLOGY}

This research aims to illustrate the differences in human resource conditions between innovation- and imitation based economies. Measuring country-specific human characteristics, variables from Global Innovation Index (GII) published by INSEAD are used. The GII covers 127 countries to measure their innovative performance. The GII relies on two sub-indices - the Innovation Input Sub-Index and the Innovation Output Sub-Index - each built around pillars. The Innovation Input Sub-Index includes 5 pillars (Institutions, Human capital and research, Infrastructure, Market sophistication, Business sophistication), while Innovation Output Sub-Index includes only two pillars (Knowledge and technology outputs, Creative outputs). Each pillar is divided into three sub-pillars, each of which is composed of individual indicators, for a total of 81 indicators in 2017. One of these pillars is Human capital and research which measures the human resource conditions of innovative performance (see the structure of this pillar in Table 1).

Table 1.

THE STRUCTURE OF THE HUMAN CAPITAL AND RESEARCH PILLAR OF GLOBAL INNOVATION INDEX

\begin{tabular}{|l|l|l|}
\hline \multicolumn{3}{|c|}{ HUMAN CAPITAL AND RESEARCH } \\
\hline Education & Tertiary education & Research and development $(R \& D)$ \\
\hline Expenditure on education & Tertiary enrolment & Researchers \\
\hline $\begin{array}{l}\text { Government expenditure on } \\
\text { education per pupil, secondary }\end{array}$ & $\begin{array}{l}\text { Graduates in science and } \\
\text { engineering }\end{array}$ & $\begin{array}{l}\text { Gross expenditure on R\&D } \\
\text { (GERD) }\end{array}$ \\
\hline School life expectancy & $\begin{array}{l}\text { Tertiary level inbound } \\
\text { mobility }\end{array}$ & $\begin{array}{l}\text { Global R\&D companies, average } \\
\text { expenditure top 3 }\end{array}$ \\
\cline { 1 - 1 } $\begin{array}{l}\text { Assessment in reading, } \\
\text { mathematics, and science }\end{array}$ & & $\begin{array}{l}\text { QS university ranking average } \\
\text { score top 3 universities }\end{array}$ \\
\cline { 1 - 1 } Pupil-teacher ratio, secondary & & \multicolumn{2}{l}{}
\end{tabular}

Source: own construction based on Dutta, Lanvin \& Wunsch-Vincent (2017)

There are nine variables in Human capital and research pillar which are linked to human resource conditions of technological progress. Based on the GII 2017, the main characteristics of the indicators can be summarized as follows. The variable of government operating expenditures in education as a percentage of gross domestic product $(G D P)$ and the variable of government spending on educa- 
tion divided by the total number of secondary students as a percentage of GDP per capita are quantifying the funding side of education. The qualitative side of human resource conditions can be measured by school life expectancy (total number of years of schooling) and assessment in reading, mathematics, and science (PISA average scales in reading, mathematics, and science). There are some variables which measure the participation in higher education, i.e. tertiary enrolment (the ratio of total tertiary enrolment), graduates in science and engineering (the share of all tertiary graduates in science, manufacturing, engineering, and construction over all tertiary graduates). To create new knowledge, the well-qualified human resources are essential in an economy, so higher education is so relevant for innovation. The pupil-teacher ratio in secondary schools reflects the efficiency of secondary education which is the basis of further education. The variable of tertiary level inbound mobility measures the number of students from abroad studying in a given country, as a percentage of the total tertiary enrolment in that country. This mobility indicator can reflect knowledge spillover between countries and the openness of a country to new knowledge. The number of researchers is the most commonly used indicator for measuring the human resource condition of a higher level knowledge creation. Researchers in R\&D are professionals engaged in the conception or creation of new knowledge, products, processes, methods, or systems and in the management of the projects concerned.

\section{RESEARCH QUESTION 1}

\section{In which areas of human resource conditions there are significant differences between innovation- and imitation-based economies?}

Using non-parametric statistical methods, the human resource conditions are compared in innovation- and imitation-based economies. Based on the Kolmogorov-Smirnov normality Test, there is no normal distribution among pupilteacher ratio (secondary), tertiary level inbound mobility and researchers. Because of this, the Independent-Samples Median Test can be used to compare the medians between two groups instead of the more frequently used $T$ test which requires the normal distribution of variables. Based on these hypothesis testing, the important human factors can be emphasized to know which ones can differentiate the innovation- and imitation-based economies. In GII database there are rankings of countries in all fields, so it can be controlled with rank correlation how similar the rankings of countries in human resource conditions. Kendall rank correlation coefficient is a non-parametric hypothesis test which is used to measure the relationship between ordinal measurement level variables. 


\section{RESEARCH QUESTION 2}

\section{Which variables related to human resource conditions determine the} most whether a country belongs to the innovator or the imitator cluster?

It can be examined which human factor(s) determine(s) the most that a country belongs to the innovator or the imitator cluster. For this purpose, a multivariate statistical method based on group formation, i.e. discriminant analysis can be used to analyze the relationship between a nonmetric, nominal measurement level, a group-forming dependent variable, and independent metric variables. This method is suitable to identify variables that can significantly differentiate groups (Sajtos \& Mitev, 2007).

\section{MAIN FINDINGS RELATED TO THE HUMAN RESOURCE CONDITIONS OF TECHNOLOGICAL PROGRESS}

As a first step in the analysis, it has been examined in which human resource indicators is there a significant difference between innovation and imitation-driven countries. The Independent-Samples Median Test was used, results can be seen in Table 2. 
Table 2.

THE RESULTS OF THE INDEPENDENT-SAMPLES MEDIAN TEST

\begin{tabular}{|l|r|r|r|}
\hline Null Hypothesis & Sig. & \begin{tabular}{c}
$|c|$ \\
\cline { 3 - 4 } \\
Innovation- \\
based \\
economies
\end{tabular} & $\begin{array}{c}\text { Imitation- } \\
\text { based } \\
\text { economies }\end{array}$ \\
\hline $\begin{array}{l}\text { The medians of Expenditure on education are the same } \\
\text { across categories of innovation- and imitation-based } \\
\text { economies. }\end{array}$ & $\mathbf{0 , 0 0 1}$ & $\mathbf{5 . 6 0 0}$ & $\mathbf{4 . 6 0 0}$ \\
\hline $\begin{array}{l}\text { The medians of Government expenditure on education } \\
\text { per pupil, secondary are the same across categories of } \\
\text { innovation- and imitation-based economies. }\end{array}$ & 0,065 & 24.850 & 20.650 \\
\hline $\begin{array}{l}\text { The medians of School life expectancy are the same } \\
\text { across categories of innovation- and imitation-based } \\
\text { economies. }\end{array}$ & $\mathbf{0 , 0 0 1}$ & $\mathbf{1 7 . 2 0 0}$ & $\mathbf{1 5 . 3 5 0}$ \\
\hline $\begin{array}{l}\text { The medians of Assessment in reading, mathematics, } \\
\text { and science are the same across categories of } \\
\text { innovation- and imitation-based economies. }\end{array}$ & $\mathbf{0 , 0 0 0}$ & $\mathbf{5 0 1 . 2 0 0}$ & $\mathbf{4 4 1 . 1 5 0}$ \\
\hline $\begin{array}{l}\text { The medians of Pupil-teacher ratio, secondary are the } \\
\text { same across categories of innovation- and imitation-based } \\
\text { economies. }\end{array}$ & 0,077 & 12.000 & 11.450 \\
\hline $\begin{array}{l}\text { The medians of Tertiary enrolment are the same } \\
\text { across categories of innovation- and imitation-based } \\
\text { economies. }\end{array}$ & $\mathbf{0 , 0 0 0}$ & $\mathbf{6 8 . 8 5 0}$ & $\mathbf{5 8 . 2 0 0}$ \\
\hline $\begin{array}{l}\text { The medians of Graduates in science and engineering are } \\
\text { the same across categories of innovation- and imitation- } \\
\text { based economies. }\end{array}$ & 0,681 & 21.250 & 22.150 \\
\hline $\begin{array}{l}\text { The medians of Tertiary level inbound mobility are the } \\
\text { same across categories of innovation- and imitation- } \\
\text { based economies. }\end{array}$ & $\mathbf{0 , 0 0 0}$ & $\mathbf{1 0 . 5 5 0}$ & $\mathbf{2 . 8 0 0}$ \\
\hline $\begin{array}{l}\text { The medians of Researchers are the same across } \\
\text { categories of innovation- and imitation-based } \\
\text { economies. }\end{array}$ & $\mathbf{0 , 0 0 0}$ & $\mathbf{4 7 1 1 . 7 0 0}$ & $\mathbf{1 8 9 2 . 4 5 0}$ \\
\hline
\end{tabular}

Source: own calculations based on GII (2017)

Based on Independent-Samples Median Test, we can conclude that there is a difference in expenditure on education, school life expectancy, assessment in reading, mathematics and science, tertiary enrolment, tertiary level inbound mobility and researchers between innovation and imitation-based economies. There 
is no significant difference in terms of secondary education (Government expenditure on education per pupil, secondary and Pupil-teacher ratio, secondary) and graduates in science and engineering. In Table 3, the average values and standard deviation of the human indicators can be seen in clusters.

Table 3.

\section{MAIN DESCRIPTIVE OF HUMAN FACTORS IN INNOVATION - AND IMITATION-BASED ECONOMIES}

\begin{tabular}{|l|r|r|r|r|r|r|}
\hline \multirow{2}{*}{ Variables } & \multicolumn{3}{|c|}{$\begin{array}{c}\text { Innovation-based } \\
\text { economies }\end{array}$} & \multicolumn{3}{c|}{$\begin{array}{c}\text { Imitation-based } \\
\text { economies }\end{array}$} \\
\cline { 2 - 7 } & Mean & $\mathbf{N}$ & $\begin{array}{c}\text { Std. } \\
\text { deviation }\end{array}$ & Mean & $\mathbf{N}$ & $\begin{array}{c}\text { Std. } \\
\text { deviation }\end{array}$ \\
\hline Expenditure on education & 5,677 & 22 & 1,4455 & 4,535 & 88 & 1,6352 \\
\hline School life expectancy & 17,233 & 21 & 2,2141 & 13,303 & 88 & 2,6538 \\
\hline $\begin{array}{l}\text { Assessment in reading, mathematics } \\
\text { and science }\end{array}$ & 498,522 & 23 & 26,7892 & 439,560 & 47 & 48,6746 \\
\hline Tertiary enrolment & 68,548 & 21 & 19,3104 & 39,914 & 93 & 26,1093 \\
\hline Tertiary level inbound mobility & 14,536 & 22 & 12,3808 & 3,417 & 78 & 3,8004 \\
\hline Researchers & 4988,657 & 23 & 1664,7095 & 1022,829 & 76 & 1270,7473 \\
\hline $\begin{array}{l}\text { Government expenditure on } \\
\text { education per pupil (secondary) }\end{array}$ & 23,386 & 22 & 6,1076 & 20,066 & 79 & 9,3944 \\
\hline Pupil-teacher ratio (secondary) & 12,161 & 18 & 2,0839 & 17,409 & 87 & 8,7779 \\
\hline $\begin{array}{l}\text { Graduates in science and } \\
\text { engineering }\end{array}$ & 20,932 & 19 & 4,6349 & 21,209 & 77 & 7,9203 \\
\hline
\end{tabular}

Source: own calculations based on GII (2017)

There is a significance difference in the number of researchers between innovation- and imitation-based countries. There are more than four times more researchers on average in innovator economies than in imitator ones, but there are big differences within both groups based on the values of standard deviation. Because of the fewer number of countries, in general, the standard deviation is lower in the innovation-based cluster than in imitator one. There is also a big difference between clusters in terms of tertiary enrolment (almost twice) and tertiary level inbound mobility, which is more than four times in innovators than in imitators. Based on the average values, there is no real difference in terms of secondary education and graduates in science and engineering between groups. 
The rankings of countries can be compared using Spearman's rho which measures the correlation between rankings (see in Table 4). Spearman's rank correlation coefficient takes the values between minus one and plus one. The positive correlation signifies that the ranks of both variables are increasing, while the negative correlation signifies that as the rank of one variable is increased, the rank of the other variable is decreased. In absolute value, if the correlation coefficient is close to zero, the relationship between rankings is weak, while approaching one it is strong. The rank correlation highlights the relationship between the different fields of human resource conditions.

Table 4.

\section{RANK CORRELATION BETWEEN MAIN HUMAN FACTORS}

\begin{tabular}{|c|c|c|c|c|c|c|c|}
\hline & & $\begin{array}{l}\text { Expenditure } \\
\text { on education }\end{array}$ & $\begin{array}{l}\text { School life } \\
\text { expectancy }\end{array}$ & $\begin{array}{c}\text { Assessment } \\
\text { in reading, } \\
\text { mathematics } \\
\text { and science }\end{array}$ & $\begin{array}{c}\text { Tertiary } \\
\text { enrolment }\end{array}$ & $\begin{array}{c}\text { Tertiary } \\
\text { level } \\
\text { inbound } \\
\text { mobility }\end{array}$ & Researchers \\
\hline \multirow{3}{*}{$\begin{array}{l}\text { Expenditure } \\
\text { on education }\end{array}$} & Spearman's rho & 1,000 & $0,365^{* *}$ & $0,358^{* *}$ & $0,239^{*}$ & $0,217^{*}$ & $0,314^{* *}$ \\
\hline & Sig. (2-tailed) & &, 000 &, 004 &, 013 & ,036 &, 003 \\
\hline & $\mathrm{N}$ & 110 & 102 & 63 & 107 & 94 & 90 \\
\hline \multirow{3}{*}{$\begin{array}{l}\text { School life } \\
\text { expectancy }\end{array}$} & Spearman's rho & & 1,000 & $655^{* *}$ & $0,899^{* *}$ & $0,376^{* *}$ & $0,800^{* *}$ \\
\hline & Sig. (2-tailed) & & &, 000 &, 000 &, 000 &, 000 \\
\hline & $\mathrm{N}$ & & 109 & 66 & 109 & 94 & 91 \\
\hline \multirow{3}{*}{$\begin{array}{l}\text { Assessment } \\
\text { in reading, } \\
\text { mathematics } \\
\text { and science }\end{array}$} & Spearman's rho & & & 1,000 & $0,624^{* *}$ & $0,343^{* *}$ & $0,785^{* *}$ \\
\hline & Sig. (2-tailed) & & & & ,000 & ,006 & 000 \\
\hline & $\mathrm{N}$ & & & 70 & 67 & 63 & 65 \\
\hline \multirow{3}{*}{$\begin{array}{l}\text { Tertiary } \\
\text { enrolment }\end{array}$} & Spearman's rho & & & & 1,000 & $0,293^{* *}$ & $0,777^{* *}$ \\
\hline & Sig. (2-tailed) & & & & &, 003 &, 000 \\
\hline & $\mathrm{N}$ & & & & 114 & 98 & 94 \\
\hline \multirow{3}{*}{$\begin{array}{l}\text { Tertiary } \\
\text { level } \\
\text { inbound } \\
\text { mobility }\end{array}$} & Spearman's rho & & & & & 1,000 & $0,503^{* *}$ \\
\hline & Sig. (2-tailed) & & & & & &, 000 \\
\hline & $\mathrm{N}$ & & & & & 100 & 83 \\
\hline \multirow{3}{*}{ Researchers } & Spearman's rho & & & & & & 1,000 \\
\hline & Sig. (2-tailed) & & & & & & \\
\hline & $\mathrm{N}$ & & & & & & 99 \\
\hline
\end{tabular}

** Correlation is significant at the 0.01 level (2-tailed).

* Correlation is significant at the 0.05 level (2-tailed).

Source: own calculations based on GII (2017) 
Based on Table 4, we can conclude that there is a strong correlation between tertiary enrolment and school life expectancy $(0,899)$ rankings, researchers and school life expectancy $(0,8)$, researchers and assessment in reading, mathematics, and science $(0,785)$ and researchers and tertiary enrolment $(0,777)$. The correlation is stronger than average between school life expectancy and assessment in reading, mathematics, and science $(0,655)$, tertiary enrolment and assessment in reading, mathematics, and science $(0,624)$ and researchers and tertiary level inbound mobility $(0,503)$.

The discrimination analysis is capable of determining which indicator determines the most whether a country belongs to the innovator or the imitator cluster. In the analysis, group forming is performed similarly to cluster analysis, the dependent variable becomes group-forming, non-quantitative, while quantitative features are included in the analysis as independent variables. There is no threshold in the literature for the matching of the grouping, in these investigations $90 \%$ agreement over the group is accepted. The main objective of this method is to highlight the human factors that determine the most whether a country belongs to the innovator or the imitation group. In the discriminant analysis the stepwise method was used based on Wilks' Lambda and Mahalanobis method of distance, because according to Obádovics (2004, p.72), if we are interested in the essential variables separating the groups, the stepwise process is necessary.

Normal distribution of variables is one of the preconditions for discriminant analysis. In the case of researchers variable there is no normal distribution, so this variable is not used in the discriminant analysis. Comparing average values by Mann-Whitney U non-parametric hypothesis test, there is a significant difference between innovation- and imitation based economies. Because of this, the number of researchers can determine belonging to the performance group of countries. In the case of another variable, Tertiary level inbound mobility, the condition of normal distribution is not fulfilled either, but there are outliers that can be excluded. To do the discriminant analysis the value of the United Arab Emirates, Luxembourg and Qatar are excluded, so the distribution approaches normal one.

In the discriminant analysis, one or more discriminant functions may be created using the indicators included in the analysis. If there are two alternatives of the dependent variable, a bivariate discriminant function is applied. The separating ability of the discriminant function is determined by the Wilks' Lambda value associated with the function and the level of significance of the Chi square test. If the significance level of the test is below $5 \%$, then the discriminant function groups are distinct enough to be able to conduct the analysis. If this significance is associated with a low Wilks' Lambda value, the discriminant function discriminates strongly. The discriminating ability of a given indicator depends on the significance level of F and Chi square test and the value of Wilks' Lambda (lower value is better). The standardized canonical discriminant coefficient (SDC) shows the 
extent that a factor influences the formed groups along the discriminant function. The main results of discriminant-analysis can be seen in Table 5 .

Table 5 .

EVALUATING THE DISCRIMINANT IMPACT OF THE INDICATORS

\begin{tabular}{|l|c|c|c|c|}
\hline \multicolumn{1}{|c|}{ Variables } & $\begin{array}{c}\text { Wilks' } \\
\text { Lambda }\end{array}$ & F & Sig. & $\begin{array}{c}\text { Standardized canonical } \\
\text { discriminant coefficient }\end{array}$ \\
\hline School life expectancy & 0,598 & 34,308 & 0,000 & 0,662 \\
\hline $\begin{array}{l}\text { Assessment in reading, mathematics } \\
\text { and science }\end{array}$ & 0,684 & 23,612 & 0,000 & 0,239 \\
\hline Tertiary level inbound mobility & 0,705 & 21,390 & 0,000 & 0,507 \\
\hline Expenditure on education & 0,762 & 15,918 & 0,000 & 0,321 \\
\hline Tertiary enrolment & 0,825 & 10,856 & 0,002 & $-0,225$ \\
\hline
\end{tabular}

Source: own calculations based on GII (2017)

Based on the significance level of $F$ test of each indicator $(0,000)$, it can be stated that all variables significantly discriminate the groups. At the same time, according to Wilks' Lambda, it is also apparent that the most discriminating effect is attributed to assessment in reading, mathematics and science, as well as tertiary level inbound mobility, followed by school life expectancy. These three indicators have the strongest influence on the grouping of the countries.

The most important parameters of the function are its eigenvalue, canonical correlation, Wilks' Lambda, and Chi square. The eigenvalue of the discriminant function is 1,232 . The canonical correlation is 0,743 . The square of the canonical correlation shows that the discriminating function preserves more than 55,21\% of the information content of the two indicators in the survey, so that the two indicators are very well characterized by the population being tested. The value of Wilks' Lambda is low, 0,448. The final step of the analysis is to examine the equivalence of the original and discriminant analysis groups, see in Table 6. 
Table 6.

\section{CLASSIFICATION RESULTS OF DISCRIMINANT ANALYSIS}

\begin{tabular}{|c|c|c|c|c|c|}
\hline \multicolumn{3}{|c|}{ Group } & \multicolumn{2}{c|}{ Discriminant groups } & \multirow{2}{*}{ Total } \\
\cline { 3 - 5 } & \multirow{2}{*}{ Count } & Innovator (1) & $\mathbf{1 5}$ & 3 & 23 \\
\cline { 3 - 5 } $\begin{array}{c}\text { Original } \\
\text { clusters }\end{array}$ & \multirow{2}{*}{$\%$} & Imitator (2) & 8 & Imitator (2) & \\
\cline { 3 - 5 } & & Innovator (1) & 83,3 & 16,7 & 100 \\
\cline { 3 - 5 } & & 8,2 & 91,8 & 100 \\
\hline
\end{tabular}

Source: own calculations based on GII (2017)

The 120 countries analyzed by discriminant analysis correspond to the original classification of $90.4 \%$. Based on the discriminant analysis, for example the original innovator Israel would rather be an imitator, while Cyprus and the Czech Republic would be an innovator.

Summarizing the analysis, it can be stated that the highest gap between innovation- and imitation-based economies is in the number of researchers which is not surprising because it is the most important indicator for creating new technologies. Because of the lack of normal distribution, this variable was not included in the analysis. Based on the results of the discriminant analysis, we can conclude that in the imitator countries, school life expectancy and the quality of human resources related to PISA results need to be increased primarily in order to catch up.

\section{CONCLUSION}

The income and technological inequalities between countries can be derived from the differences in the country-specific characteristics of innovation's conditions. Innovation requires adequate human resources and institutional environment, as well as firms to innovate. Differences in human, financial and institutional conditions create technology disparities which lead to innovation- and imitation-based economies with different economic performance. This research has undertaken to illustrate the differences in human resource conditions between innovation- and imitation-based economies using non-parametric and multivariate statistical methods. We assumed that innovator and imitator countries are different in terms that innovation requires high-skilled workforce, while less skilled workers are more suitable for imitation. This research has underlined that in innovation- 
based economies there are more researchers, the tertiary enrolment and tertiary inbound mobility are higher than in imitation-based countries. In innovator countries school life expectancy is higher and the quality of human resources is better as indicated by better average PISA results. The school life expectancy is correlated with tertiary enrolment and the number of researchers, because if students spend more time in the education system, they get a higher level of knowledge that is more conducive to innovation. The result of the analysis is that there is no significant difference in secondary education between innovator and imitator countries. Therefore, increasing participation in higher education is important to adapt newer technologies in imitator countries. This research highlights that the quality of education and the enrolment rates are equally important in human resource development. In addition, not only the tertiary education plays important role in technological progress, but also the overall education system must operate well to realize development. In further research, it can be examined how countries can respond effectively to technological changes through the development of human resources.

Acknowledgements: This research is supported by the ÚNKP-17-4 National Excellence Program of the Ministry of Human Capacities.

\section{References}

Acemoglu, D., Aghion, P. \& Zilibotti, F. (2006). Distance to frontier, Selection, and Economic growth. Journal of the European Economic Association, 4(1), 37-74.

Acemoglu, D. (2009): Introduction to Modern Economic Growth. Chapter 21, Structural Transformations and Market Failures in Development. Princeton University Press, Princeton, New Jersey.

Aghion, Ph. \& Howitt, P. (2005): Growth with Quality-Improving Innovations: An Integrated Framework. In: Aghion, P. \& Durlauf, S. (eds.): Handbook of Economic Growth. The Netherlands, Amsterdam, Chapter 2, 67 - 110.

Barro, R. J. \& Sala-i-Martin, X. (1997). Technological Diffusion, Convergence, and Growth. Journal of Economic Growth, 2(1), 1-26.

Basu, S. \& Weil, D. N. (1998). Appropriate Technology and Growth. The Quarterly Journal of Economics, 113(4), 1025 - 1054.

Caselli, F. \& Coleman, W. J. (2006). The World Technology Frontier. The American Economic Review, 96(3), 499 - 522.

Csugány J. (2016). A gazdasági, technológiai és intézményi fejlettség összefüggésének empirikus vizsgálata: az innovátor és imitátor országok megkülönböztetése. [Empirical analysis in the context of economic, technological and institutional development: the distinction between innovator and imitator countries]. Competitio, 15(1), 3-21. 
Czeglédi P. (2004). Humán tôke és intézmények az endogén növekedéselmélet korai modelljeiben. [Human capital and institutions in early models of endogenous growth theory] Competitio, 3(2), 135-149.

Dutta, S., Lanvin, B. \& Wunsch-Vincent, S. (2017). The Global Innovation Index 2017 Innovation Feeding the World. Tenth Edition. Available at: https://www.globalinnovationindex.org/gii-2017-report

Fagerberg, J. (1994). Technology and International Differences in Growth Rates. Journal of Economic Literature, Vol. 32(3), 1147-1175.

Global Innovation Index 2017. Available at: https://www.globalinnovationindex.org/analysis-indicator

Growiec, J. (2006). The World Technology Frontier: What Can We Learn from the US States? Oxford Bulletin of Economic and Statistics, 74(6), 777 - 807.

Islam, R. (2010). Human Capital Composition, Proximity to Technology Frontier and Productivity Growth. MONASH University, Discussion Paper 23/10. Available at: http://www.buseco.monash.edu.au/eco/research/papers/2010/2310humanislam.pdf

Jerzmanowski, M. (2007). Total Factor Productivity Differences: Appropriate Technology vs. Efficiency. European Economic Review, 51(8), 2080 - 2110

Jones, Ch. I. (2016). The Facts of Economic Growth. In: Taylor, J. B. \& Uhlig, H. (eds.) Handbook of Macroeconomics, Chapter 1, The Netherlands, Amsterdam:Elsevier, Vol. 2A, pp. $3-69$.

Jovanovic, B. (1998). Vintage Capital and Inequality. Review of Economic Dynamics, 1(2), $497-530$.

Krugman, P. (1979): A Model of Innovation, Technology Transfer, and the World Distribution of Income. The Journal of Political Economy, Vol. 87. 2:253-266.

Lucas, R. E. (1988). On the Mechanics of Economic Development. Journal of Economic Development, 22(1), 3 - 42 .

Lucas, R. E. (1993). Making a Miracle. Econometrica, 61(2), 251-273.

Mankiw, G. N., Romer, D. \& Weil, D. N. (1992). A Contribution to the Empirics of Economic Growth. The Quarterly Journal of Economics, 107(2), 407-437.

Mokyr, J. (2004). A gazdagság gépezete - technológiai kreativitás és gazdasági haladás. [The Lever of Riches: Technological Creativity and Economic Progress]. Budapest: Nemzeti Tankönyvkiadó.

Nelson, R. R. \& Phelps, E. S. (1966). Investment in Humans, Technological Diffusion, and Economic Growth. The American Economic Review, 56(1/2), 69 - 75.

Obádovics Cs. (2004). A vidéki munkanélküliség térségi eloszlásának elemzése. [Analysis of the regional distribution of rural unemployment]. Doctoral dissertation. Gödöllő: Szent István University, Doctoral School of Management and Business Administration.

Romer, P. M. (1993). Two Strategies for Economic Development: Using Ideas and Producing Ideas. Proceedings of the World Bank Annual Research Conference on Development Economics 1992, pp. 63 - 90. 
Sajtos L. \& Mitev A. (2007). SPSS kutatási és adatelemzési kézikönyv. [SPSS research and data analysis manual]. Budapest: Alinea.

Solow, R. M. (1957): Technical Change and the Aggregate Production Function. The Review of Economics and Statistics, Vol. 39(3), pp. 312-320.

Tánczos T. (2011). A társadalmi és gazdasági fejlettség térbeli folyamatvizsgálata Magyarországon. [Spatial process assessment of social and economic development in Hungary]. Doctoral dissertation. Gödöllő: Szent István University, Doctoral School of Management and Business Administration.

Williamson, S. D. (2007). Macroeconomics. 3rd edition, Pearson.

\title{
EMPIRIJSKI DOKAZI O RAZLIKAMA U RAZVOJU LJUDSKIH RESURSA IZMEĐU INOVACIJSKIH I IMITACIJSKIH EKONOMIJA
}

\author{
Sažetak
}

Dohodovne i tehnološke nejednakosti između zemalja mogu se derivirati iz razlika u specifičnim uvjetima tehnološkog napretka u pojedinim zemljama. Inovacija zahtijeva odgovarajuce ljudske resurse i institucionalno okruženje, kao i tvrtke za inoviranje. Razlike u ljudskim, financijskim i institucionalnim uvjetima stvaraju tehnološke razlike što dovodi do inovativnih i imitacijskih gospodarstava s različitim ekonomskim performansama. Tehnološke promjene u gospodarstvu omogućene su stvaranjem i primjenom novih znanja. Stoga se tehnološki napredak može tumačiti kao specifičan oblik akumulacije znanja, u kojem ljudski resursi zemalja imaju ključnu ulogu. Ovo istraživanje ima za cilj ilustrirati nejednakosti u inovacijama razvoja ljudskih resursa između inovativnih i imitacijskih gospodarstava zasnovanih na neparametrijskim i multivarijantnim statističkim metodama. Varijable ljudskog kapitala i indeksa globalnih inovacija usporedit će se koristeći različite analitičke tehnike kako bi se istaknulo gdje su veće razlike u razvoju ljudskih resursa između skupina zemalja. Glavni rezultat ovog istraživanja je da je ukupan broj godina školovanja čimbenik u kojem su zemlje najviše razlikuju, pa je obrazovanje važno za zemlje imitatorice kako bi dostignule zemlje inovatore.

Ključne riječi: tehnološki napredak, inovacija, imitacija, ljudski resursi 